\title{
DITERPENOID ACIDS FROM THE LEAVES OF ARMAND PINE
}

\author{
JiM-Min FANG, Chi-I LANG, WeI-Lieh Chen and Yu-Shia Cheng* \\ Department of Chemistry, National Taiwan University, Taipei, Taiwan 10764, Republic of China
}

(Received 5 November 1990)

Key Word Index-Pinus armandii; Pinaceae; diterpenoidal acids; labdane-type; abietane-type; coumarin; flavone; lignans; sterols.

\begin{abstract}
Umbelliferone, naringenin 4',7-dimethyl ether, matairesinol, pinoresinol, sitosterol, campesterol and seven diterpenes were isolated from the leaves of armand pine. The diterpenes are carboxylic acids and methyl esters of the labdane- and abietane types including lambertianic acid, pinusolide, 16-hydroxylabda-8(17),13-diene-15,19-dioic acid butenolide, isocupressic acid, 15-hydroxydehydroabietic acid, 15-nor-16-hydroxy-14-oxolabd-8(17)-enoic acid and 7,8-dihydro-8,15-dihydroxyabietic acid. Among them, the latter two compounds are newly found in nature.
\end{abstract}

\section{INTRODUCTION}

Pinus armandii Franchet var. mastersiana Hayata, the armand pine, is an economically important conifer indigenous to the southwest region of China [1]. We have recently isolated the flavonoids and stilbenes constituents from the heartwood [2], and a number of serratenoidal triterpenes from the bark of this plant [3]. As a continuation of this study, we report herein the diterpenes isolated from the leaves of $P$. armandii.

\section{RESULTS AND DISCUSSION}

The leaves of $P$. armandii, collected in the Central Range of Taiwan, were exhaustively extracted with acetone. The acetone extract was concentrated and the ethyl acetate soluble portion was subjected to chromatography to give seven diterpenes (1-7) and other components including a coumarin, umbelliferone (8) [4], a flavone, (-)-naringenin 4',7-dimethyl ether (9) [5], two lignans, (-)-matairesinol (10) [6,7] and (+)-pinoresinol (11) [8], as well as a mixture of sitosterol and campesterol (3:7).

By spectral analyses (IR, MS, ${ }^{1} \mathrm{H}$ and ${ }^{13} \mathrm{C}$ NMR), most of diterpenoidal constituents were found to be carboxylic acids having either the labdane- or abietane-type skeleton. The NMR signals for the geminal protons $(\mathrm{H}-17)$ of exocyclic double bond were readily observed in the region of $\delta 4.5-5.0$. Compound 1 showed a characteristic IR absorption (3500-2500 $\left.\mathrm{cm}^{-1}\right)$ for a carboxylic acid and the NMR resonances at $\delta 6.23,7.16$ and 7.32 attributable to three aromatic protons of a 3-substituted furan. Thus, $1, \operatorname{mp~} 127-128^{\circ},[\alpha]_{\mathrm{D}}^{25}+55^{\circ}$ (EtOH; c 0.69), was identified as lambertianic acid [9]. Compound 2 contained the functional groups of a methyl ester $\left(v_{\max } 1712 \mathrm{~cm}^{-1}, \delta_{\mathrm{H}} 3.72\right)$ and an $\alpha, \beta$-unsaturated $\gamma$-lactone $\left(\left[v_{\max } 1743 \mathrm{~cm}^{-1}, \delta_{\mathrm{H}} 7.24(\mathrm{H}-14)\right.\right.$ and $\left.4.88(\mathrm{H}-15)\right]$. Compound $2, \mathrm{mp} 84-85^{\circ},[\alpha]_{\mathrm{D}}^{25}+24^{\circ}$, was identified as pinusolide [10]. Compounds 3 and 4 were readily determined to be 16-hydroxylabda-8(17),13-diene-15,19-dioic acid butenolide and $(+)$-isocupressic acid, which were recently isolated by us from the leaves of Calocedrus formosana [11]. Compound 3 consisted of two C-16 epimers $(9: 11)$ as revealed by two $H-16$ signals found at $\delta 6.04(b r s)$ and $6.08(b r s)$. Compound 5 exhibited the acid, hydroxyl and carbonyl group IR absorptions at $3300,3000-2500,1720$ and $1690 \mathrm{~cm}^{-1}$, respectively. The ${ }^{13}$ C NMR spectrum displayed only 19 signals, of which $\delta 67.9$ and 209.9 were attributable to the carbons of an $\alpha$ hydroxyketone. The exact mass of the parent peak at $\mathrm{m} / \mathrm{z}$ 322.214 in the mass spectrum indicate a molecular formula $\mathrm{C}_{19} \mathrm{H}_{30} \mathrm{O}_{4}$. Thus, the new structure of a norlabdane, 15-nor-16-hydroxy-14-oxolabd-8(17)-enoic acid, was assigned to compound 5 . The complete ${ }^{1} \mathrm{H}$ and ${ }^{13} \mathrm{CNMR}$ assignments were deduced from the ${ }^{1} \mathrm{H}-{ }^{1} \mathrm{H}$ and ${ }^{13} \mathrm{C}-{ }^{1} \mathrm{H}$ correlation spectra. The proton resonance of Me-10 occurring at an unusually high field $\delta 0.52$ was ascribed to the shielding effect of the axial carboxylic group. The H-9 was considered to be axial because its resonance at $\delta 1.53$ displayed the $W$-type coupling with the resonance of $\mathrm{Me}-10$. The axial orientation of $\mathrm{H}-5$ was similarly determined.

An abietane-type diterpenoidal acid (6) showing three aromatic protons at $\delta 7.16(\mathrm{br} s)$ and $7.22(\mathrm{br} \mathrm{s}, 2 \mathrm{H})$ was identified as $(+)-15$-hydroxydehydroabietic acid by comparison of $\mathrm{mp}$ and $[\alpha]$ values with those of an authentic sample $[12,13]$. Compound 7 was assigned as 7,8dihydro-8,15-dihydroxyabietic acid from its physical and spectral properties. The structure of its methyl ester (7a) was further supported by the ${ }^{13}$ C NMR spectrum. However, the ester $7 \mathfrak{a}$ was rather unstable in chloroform- $d$ and it lost water molecules to give a triene $\mathbf{7 b}$, presumably catalysed by a trace of mineral acid present in the solution. Compound 7 was tentatively assigned to have the axial C-8 hydroxy group by considering the nature of the facile dehydration of the ester 7a. The occurrence of nor-labdanoic acid 5 and the unstable dihydroxyabietic acid 7 is of interest from the biogenetic aspect.

\section{EXPERIMENTAL}

Plant material. The leaves of Pinus armandii Fr. var. mastersiana Hay. were collected in Tayulin mountain ( $2600 \mathrm{~m}$ altitude), Taichung, in August 1985. A voucher specimen, identified by Dr $\mathrm{Ta}-W e i \mathrm{Hu}$, has been deposited in the Herbarium of the Taiwan Forestry Institute. The leaves $(570 \mathrm{~g})$ were extracted $\times 3$ with $\mathrm{Me}_{2} \mathrm{CO}$. The combined $\mathrm{Me}_{2} \mathrm{CO}$ extracts were concd and re- 


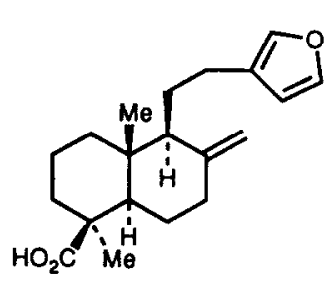

1

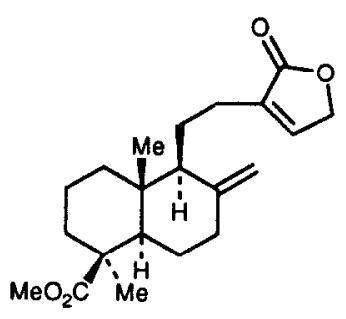

2

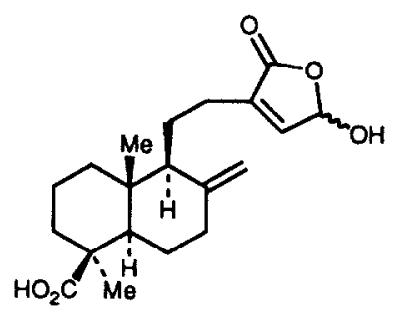

3

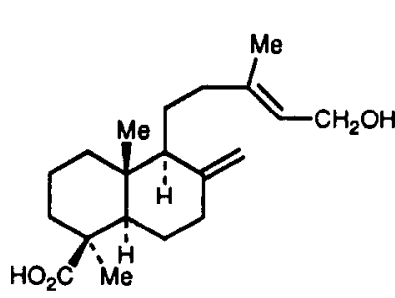

4

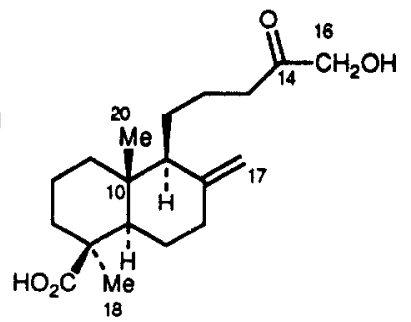

5

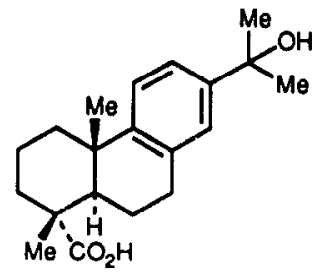

6

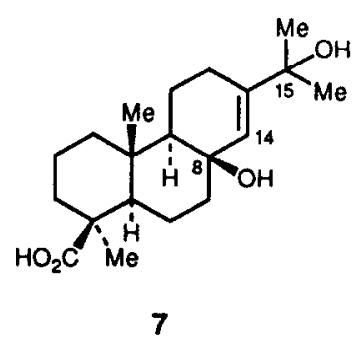

为

8

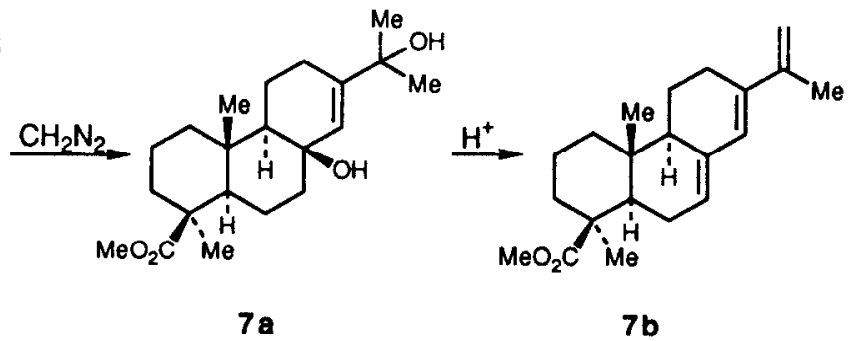<smiles>COc1ccc([C@H]2CC(=O)c3c(O)cc(OC)cc3O2)cc1</smiles>

9<smiles>COc1cc(C[C@@H]2C(=O)OCC2(Cc2ccc(O)c(OC)c2)Cc2ccc(O)c(OC)c2)ccc1O</smiles>

10

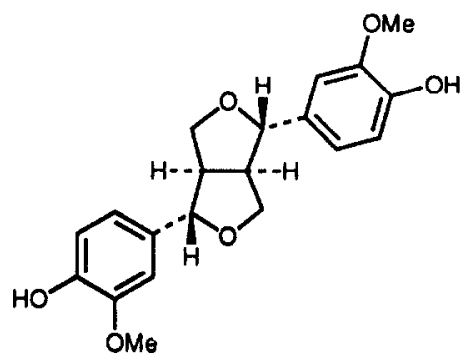

11 
extracted with EtOAc to give $15.3 \mathrm{~g}$ of crude mixt. The mixt. were subjected to $\mathrm{CC}$ by elution with the gradients of hexane and EtOAc to give compounds $1(50 \mathrm{mg}), 6(14 \mathrm{mg}), 7(20 \mathrm{mg}), 2$ (43 mg), 4 (30 mg), 8 (13 mg), 9 ( $8 \mathrm{mg}), 3(87 \mathrm{mg}), 5(171 \mathrm{mg}), 10$ $(72 \mathrm{mg})$ and $11(18 \mathrm{mg})$ according to the ascending order of polarity.

15-nor-16-Hydroxy-14-oxolabd-8(17)-enoic acid (5). Oil, $\boldsymbol{R}_{f}$ 0.28 (EtOAc-hexane, $2: 3)$, $[\alpha]_{\mathrm{D}}^{25}+50.0^{\circ}\left(\mathrm{CHCl}_{3} ; c 8.5\right)$. IR $v_{\max }^{\text {neat }}$ $\mathrm{cm}^{-1}: 3300(\mathrm{OH}), 1720(\mathrm{C}=\mathrm{O}), 3000-2500,1690\left(\mathrm{CO}_{2} \mathrm{H}\right), 889$. ${ }^{1} \mathrm{H}$ NMR $\left(\mathrm{CDCl}_{3}\right): \delta 0.52(3 \mathrm{H}, s, \mathrm{Me}-10), 0.95(\mathrm{H}-3), 1.10(\mathrm{H}-1 \alpha)$, 1.18 (3H, s, Me-4), 1.28 (H-5, H-12), 1.38 (H-11), 1.43 (H-12), 1.45 (H-2), 1.53 (H-9), 1.73 (H-1 B), 1.75 (H-11), 1.78 (H-2, H-6), 1.85 (H-7), 1.93 (H-6), 2.10 (br d, J=12 Hz, H-3), 2.33 (H-7 and two $\mathrm{H}-13), 4.19(2 \mathrm{H}, \mathrm{s}, \mathrm{H}-16), 4.46(1 \mathrm{H}, \mathrm{br}$ s, H-17), $4.80(1 \mathrm{H}, \mathrm{br}$, $\mathrm{H}-$ 17). ${ }^{13} \mathrm{CNMR}$ (75 MHz): $\delta 12.6$ (C-20), 19.8 (C-2), 22.8 (C-11), 23.4 (C-12), 25.9 (C-6), 28.9 (C-18), 37.8 (C-3), 38.5 (C-7), 38.6 (C13), 39.0 (C-1), 40.3 (C-10), 44.1 (C-4), 55.9 (C-9), 56.2 (C-5), 67.9 (C-16), 106.5 (C-17), 147.6 (C-8), 183.7 (C-19), 209.9 (C-14). EIMS $(70 \mathrm{eV}) \mathrm{m} / \mathrm{z}$ (rel. int.) $322[\mathrm{M}]^{+}$(2), 304 (2), 276 (17), 248 (21), 221 (16), 189 (4), 167 (32), 161 (28), 139 (33), 121 (100). Exact mass $\mathrm{C}_{19} \mathrm{H}_{30} \mathrm{O}_{4}$ requires 322.2144. Found 322.2141.

7,8-Dihydro-8,15-dihydroxyabietic acid (7). Oil, $[\alpha]_{\mathrm{D}}^{25}-43.6^{\circ}$ (MeOH; $c 0.3)$. IR $\nu_{\max }^{\text {neal }} \mathrm{cm}^{-1}: 3400,1690$. EIMS $(70 \mathrm{eV}) \mathrm{m} / \mathrm{z}$ (rel. int.): $318\left[\mathrm{M}-\mathrm{H}_{2} \mathrm{O}\right]^{+}(10), 300(24), 285(6), 277(100), 257$ (8), 239 (7), 231 (33), $213(10)$. ${ }^{1} \mathrm{H}$ NMR $\left(\mathrm{Me}_{2} \mathrm{CO}-d_{6}\right) ; \delta 0.83$ (3H, $s$, Me-10), 1.07 (3H, s, Me-4), 1.14 (3H, Me-15), 1.18 (3H, s, Me-15), $5.72(1 \mathrm{H}, b r s)$. The acid 7 was converted to a methyl ester by treating with a methanolic soln of $\mathrm{CH}_{2} \mathrm{~N}_{2}$. Oil, $[\alpha]_{D}^{25}-12.2^{\circ}$ $\left(\mathrm{CHCl}_{3} ; c\right.$ 0.7). IR $v_{\max }^{\mathrm{KBr}} \mathrm{cm}^{-1}: 3387(\mathrm{OH}), 2940,1694 .{ }^{1} \mathrm{H}$ NMR $\left(\mathrm{CDCl}_{3}\right): \delta 0.79(3 \mathrm{H}, \mathrm{s}, \mathrm{Me}-10), 1.10(3 \mathrm{H}, \mathrm{s}, \mathrm{Me}-4), 1.18(6 \mathrm{H}, \mathrm{s}, \mathrm{Me}-$ 15), $3.63(3 \mathrm{H}, \mathrm{s}, \mathrm{OMe}), 5.72(1 \mathrm{H}, b r s) .{ }^{13} \mathrm{CNMR}\left(\mathrm{CDCl}_{3}\right): \delta 14.9$ (C-20), 17.0 (C-18), 17.6, 18.0, 24.2, 24.3 (C-16), 24.4 (C-17), 29.7, 34.9, 36.9, 37.4 (C-10), 38.2, 47.4 (C-4), 48.8, 51.2, $51.9\left(\mathrm{OCH}_{3}\right)$, 74.1 (C-15), 74.7 (C-8), 123.5 (C-14), 144.0 (C-13), 179.2 (C-19). The ester underwent dehydration on standing in $\mathrm{CDCl}_{3}$ soln to give a triene. ${ }^{1} \mathrm{H}$ NMR $\left(\mathrm{CDCl}_{3}\right): \delta 0.81(3 \mathrm{H}, s, \mathrm{Me}-10), 1.24(3 \mathrm{H}, \mathrm{s}$, $\mathrm{Me}-4), 1.90\left(3 \mathrm{H}, s\right.$, vinyl Me), $3.62\left(3 \mathrm{H}, s, \mathrm{CO}_{2} \mathrm{Me}\right), 4.89(1 \mathrm{H}, \mathrm{s}$, olefinic $\mathrm{H}), 5.01(1 \mathrm{H}, s$, olefinic $\mathrm{H}), 5.56(1 \mathrm{H}, b r s, \mathrm{H}-14), 6.13(1 \mathrm{H}$, br s, H-7). ${ }^{13} \mathrm{CNMR}\left(\mathrm{CDCl}_{3}\right): \delta 14.0$ (C-20), 17.0 (C-18), 18.1 (C-2), 20.5 (C-17), 22.1 (C-11), 26.0 (C-12), 26.2 (C-6), 34.5 (C-10), 37.1 (C-3), 38.3 (C-1), 45.0 (C-9), 46.6 (C-4), 50.3 (C-5), 51.9 $\left(\mathrm{CO}_{2} \mathrm{Me}\right), 111.2$ (C-16), 124.7 (C-14), 127.0 (C-7), 135.8 (C-15), 136.4 (C-8), 143.2 (C-13), 179.0 (C-19).

Acknowledgement-We are grateful to $\mathrm{Dr} \mathrm{Ta}-\mathrm{Wei} \mathrm{Hu}$ (Department of Forestry, the Chinese Culture University) for collection of plant material, and to the National Science Council (Republic of China) for financial support.

\section{REFERENCES}

1. Li, H. L. (1975) in Flora of Taiwan Vol. 1, 518-525. Epoch, Taiwan.

2. Fang, J. M., Su, W. C. and Cheng, Y. S. (1988) Phytochemistry 27, 1395.

3. Fang, J. M., Tsai, W. Y. and Cheng, Y. S. (1991) Phytochemistry 30 (in press).

4. Kalyanmay, S. and Bagchi, P. (1959) J. Chem. Soc. 24, 316.

5. Narasimhachari, N. and von Rudloff, E. (1962) Can. J. Chem. 40, 1123.

6. Corrie, J. E. T., Green, G. H., Ritchie, E. and Taylor, W. C. (1970) Aust. J. Chem. 23, 133.

7. Fang, J. M., Wei, K. M. and Cheng, Y. S. (1985) J. Chin. Chem. Soc. (Taipei) 32, 75.

8. Freudenberg, K. and Sidhu, G. S. (1960) Tetrahedron Letters 3.

9. Dauben, W. G. and German, V. F. (1966) Tetrahedron 22, 679.

10. Raldugin, V. A., Lisina, A. I., Kashatonova, N. K. and Pentegova, V. A. (1970) Khim. Prir. Soedin. 541.

11. Fang, J. M., Hsu, K. C. and Cheng, Y. S. (1989) Phytochemistry 28, 1173.

12. Carman, R. M. and Marty, R. A. (1970) Aust. J. Chem. 23, 1457.

13. Cheng, Y. S. and Lu, S. B. (1978) J. Chin. Chem. Soc. (Taipei) 25, 47. 